\title{
The Potential of the ePortfolio as a Recruitment Tool: From the Perspective of HR Directors
}

\author{
https://doi.org/10.3991/ijim.v14i03.11557 \\ Monika Ciesielkiewicz ${ }^{(\varpi)}$ \\ Villanueva-Complutense University of Madrid, Madrid, Spain \\ mciesielkiewicz@villanueva.edu \\ Claire Frances Bonilla \\ Universidad a Distancia de Madrid, Madrid, Spain \\ Carlos Olave López de Ayala \\ Global HR at LG Electronics, , Seoul, South Korea
}

\begin{abstract}
In this paper, the authors explore the potential of the electronic portfolio (ePortfolio) as a recruitment tool, in particular whether Human Resources directors would be willing to use it during the recruitment and selection process. The ePortfolio presents, documents, reflects on, and fosters students' skills, credentials, certificates and diverse formal and informal experiences in a structured and well-organized manner. Because the ePortfolio is, by nature, flexible and adaptable, an ePortfolio developed with the help of professors over the course of a students' studies can easily be incorporated into professional networking platforms as a job search tool and showcase the skills required for a successful applicant. It is often said that the difference between what is taught in the academic world and the practical skills that are required by the business sector make it difficult for students to access the labor market. The ePortfolio may help to reconcile both worlds. In order to examine whether Human Resources directors are willing to use an ePortfolio as a recruitment tool, a survey was carried out among fifty-two Human Resources directors. The research findings reveal that an educational ePortfolio can count on significant approval in the business sector. This research study is relevant as it provides valuable information on this topic and it is the only one to date, conducted among HR directors in the context of Spanish-speaking countries.
\end{abstract}

Keywords - ePortfolio, educational technology, higher education, employability, human resources.

\section{Introduction}

Nowadays ICTs are transforming our lives, from the classroom to the boardroom and beyond. Lifelong learning has been hailed as an important tool for thriving in this knowledge-driven society. The Bologna Process mandates provisions for lifelong learning [1][2]. Delors [3] declares that lifelong learning is "an imperative of democracy" 
(p. 100). Additionally, UNESCO and the Office for Economic Co-operation and Development (OECD), describe lifelong learning as one of the integral components of “economic prosperity and social stability" (p. 1) [4]. The Australian Department of Education, Science and Training (DEST) identifies lifelong learning as a key skill for "employability in the future" (p. 10) [5]. It seems clear that apart from being a European Union requirement, lifelong learning is a reality in, as well as a demand of, the labor market into which students must assimilate and adapt, in an era of globalization and constant technological change. The ePortfolio is an effective instrument to address these concerns, as it promotes formal and informal lifelong learning while also being a useful tool for insertion into the labor market [6][7].

The ePortfolio has gained international acceptance. It enjoys widespread use within many of the member states of the Council of Europe [8-12]. Educational institutions in Canada and New Zealand have been implementing the ePortfolio for a number of years [13-16]. The use of ePortfolios has also become a common practice in the United States, as surveys indicate that $54 \%$ of American students have, at one point or another in their academic career, used or created an ePortfolio [17][18]. Furthermore, in Australia the government sponsored a national initiative for the implementation of the ePortfolio [19][20].

The uses and forms of implementation of the ePortfolio are varied. Barker [21] suggests that all students begin an ePortfolio in primary school with periodic updates throughout their lives. The ePortfolio can be an effective constructivist-learning environment, by providing a platform for students to build and reflect on their experiences and achievements [22]. Teacher development and assessment has particularly benefited from the implementation of ePortfolios. In the United States, education students are often required to build ePortfolios, and encouraged to continue using them once they have begun their teaching career [22][23]. In Australia, educators are required to create an ePortfolio to demonstrate evidence of having mastered the competences mandated by the Australian Professional Standards for Graduate Teachers [24].

However, numerous scholars claim [25] that the difference between what is taught in the academic world and the practical skills that are required by the business sector make it difficult for students to access the labor market. Employers report that college graduates entering the workforce lack the skills and competences that are necessary to successfully integrate into employment [26]. Furthermore, the needs of the labor market are shifting due to economic migration and the aging of the workforce [27]. As such, effectively matching workers to the employment best suited for them is crucial. Lievens [27] explicitly states that he believes that ePortfolios "can prove to be a valuable instrument for matching workers to jobs" (p. 163). Weber [26] asserts that the soft skills make one candidate stand out from another. The employers who participated in Weber's study "believed ePortfolios enable an employer to learn more about a candidate's personality and background, creativity and thought process, ability to work effectively within a team, and adaptability and ability to cross train" (p. 62). 


\section{The ePortfolio as a Recruitment Tool}

It must be acknowledged that the use of ePortfolio for recruitment purposes is still at an early phase of development [28][25][27], however there are a number of studies that are worth mentioning. Ward and Moser [29] identified the type of information the HR managers considered most valuable. Among the items they would like to see in an ePortfolio are: resumes/references (93\%), written work (39\%), projects $(37 \%)$, presentations $(33 \%)$, lesson plans $(23 \%)$, case studies $(7 \%)$, and artistic performances $(6 \%)$. They also discovered that $95 \%$ of employers would rather receive an ePortfolio as a link to a website than in any other form or device. Furthermore, research performed by $\mathrm{Yu}[30]$ suggests that the industry into which the student is entering may best determine the suggested content of the ePortfolio; for example, someone entering the tourism industry should consider including certifications or other evidence of speaking a foreign language. However, Blair and Godsall [31] admit that most students are not aware of what type of documentation is required by employers. As such, there is a clear need for more training on ePortfolios for both educators and students [32-36].

Students, especially recent graduates seeking employment, could highly benefit from an ePortfolio that would effectively serve as a multimedia CV that could be sent to HR managers. Fung and Wong [37] assure that the ePortfolio "can provide students with both the evidence and the language to convey their achievements to employers" (p. 92). This was confirmed in research by Ring, Waugaman and Brackett [38] in which students who had used an ePortfolio were able to more effectively convey their achievements in a mock job interview. Additionally, Wetcho and Na-Songkhla [39] assert that the ePortfolio is a useful tool for building self-efficacy regarding career decisions. They claim that it can help students to make better decisions about their education and professional careers.

Interest in the ePortfolio as a recruitment tool is growing. According to a survey conducted for the Association of American Colleges and Universities (AAC\&U) by Hart Research Associates [40], four out of five (83\%) employers, including executives of private sector and nonprofit organizations such as owners, CEOs, presidents, C-suite level executives, and vice presidents, find students' ePortfolios to be a useful tool for candidate screening and hiring. The Notre Dame ePortfolio Engagement Program (nDEEP) organized a focus group for job recruiters from large corporations to discuss the results of the AAC\&U research. Although the participants stressed that an ePortfolio is not a substitute for engaging interview skills, $91 \%$ of the recruiters indicated that they would view a student's ePortfolio if a link were sent in a follow-up email, post interview. The recruiters seemed impressed by the potential of the ePortfolio as a recruitment tool. In fact, $72 \%$ of the participants indicated that the ePortfolio would be "a valuable tool for their company's recruiting" [41]. These results suggest a promising future for the ePortfolio as a recruitment tool.

This paper explores the question of whether the educational ePortfolio can help to reconcile the academic and professional worlds, in order to enhance the employability of young people in the job market. Specifically, the following research questions are explored: 
- Would HR directors use an ePortfolio to select candidates for a job at some stage of the recruitment process?

- Would HR directors be willing to review only the ePortfolio of the best candidate for a job?

- Would HR directors be willing to review the ePortfolio of the 3 best candidates for a job?

- Would HR directors be open to reviewing the ePortfolios of all candidates to select the best ones for a job?

- Do HR directors consider the ePortfolio a useful tool to obtain wider and more detailed information on candidates who apply for a job?

\section{$3 \quad$ Method}

\subsection{Participants}

The participants in the study were fifty-two human resources (HR) directors who voluntarily and anonymously completed the survey between January and July of 2015.

The survey was sent to $80 \mathrm{HR}$ directors, and a total of 52 responded, representing a response rate of $65 \%$. Though the respondents hail from diverse countries, the majority work in Spain.

The HR directors who participated in the survey were contacted through the Spanish Association of Human Resources Directors (AEDRH: Asociación Española de Directores de Recursos Humanos). More information can be found in the Data Analysis section.

\subsection{Instrument}

A six-item questionnaire was developed to inquire as to whether HR directors would be willing to use the ePortfolio for recruitment purposes. The first question addresses the country where the survey respondents are currently working. The following questions are closed-ended and directly related to the topic of the present research. The questions were selected and adapted from validated surveys used in research by Ward and Moser [29], Australian ePortfolio Project [42] and AAC\&U \& Hart Research Associates [40].

\subsection{Procedures}

This quantitative research analyzed data gathered by means of a survey. Its main goal was to analyze the willingness of HR directors to use ePortfolios as a recruitment tool.

Once potential participants were identified, an email invitation was sent to the HR directors containing a link to an anonymous questionnaire. A short description of the ePortfolio and various links to sample ePortfolios were provided at the beginning of the survey for those participants who were not familiar with or had never seen an ePortfolio. 
The online questionnaire was administered via Google Forms, then collected and transferred into Excel for statistical calculations and graphing. Wuetherick and Dickinson [43] believe "a questionnaire administered online is a desirable way to collect information as computer access is increasingly widespread, email makes it very easy to contact participants and follow-up reminders are easy and inexpensive" (p.41).

\subsection{Results}

In the first question, HR directors were asked about the country in which they were currently working. When examining the countries separately, $77 \%$ of the respondents worked in Spain, $10 \%$ in other European countries such as Portugal, Italy, Holland and Sweden and $13 \%$ in Latin America, namely Mexico, Colombia, Brazil and Argentina. However, all the participants were native Spanish speakers.

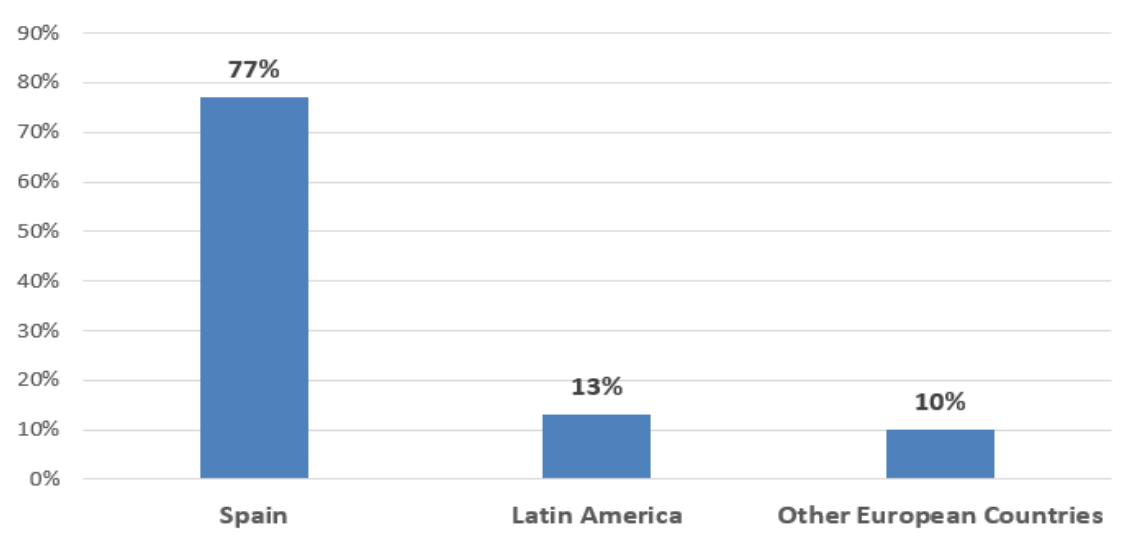

Fig. 1. HR Directors' country distribution.

The second question examined whether the survey participants would use an ePortfolio to select candidates for a job post at some stage of the recruitment process. The vast majority of the HR directors $(83 \%)$ indicated that they would use the ePortfolio to select candidates for a job, with the breakdown as follows: $23 \%$ strongly agreed, $23 \%$ agreed and $37 \%$ somewhat agreed. Only $2 \%$ strongly disagreed, $4 \%$ somewhat agreed and $11 \%$ neither agreed nor disagreed. 


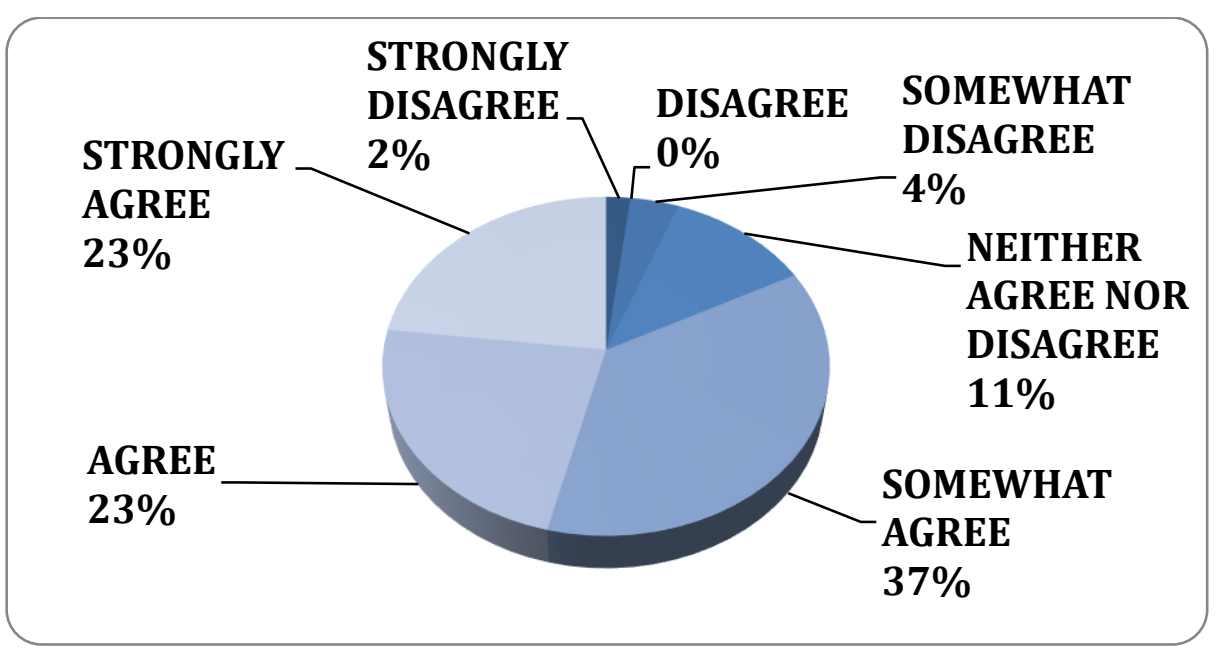

Fig. 2. Would HR directors use an ePortfolio to select candidates for a job at some stage of the recruitment process?

In the next question the survey participants were asked whether they would be willing to review the ePortfolio of the best candidate for job post. According to the data collected, $76 \%$ of the survey participants indicated that they would, among them $50 \%$ strongly agreed, $13 \%$ agreed and $13 \%$ somewhat agreed. On the other hand, $2 \%$ somewhat disagreed and $12 \%$ disagreed. None of the survey participants strongly disagreed. Finally, $10 \%$ neither agreed nor disagreed.

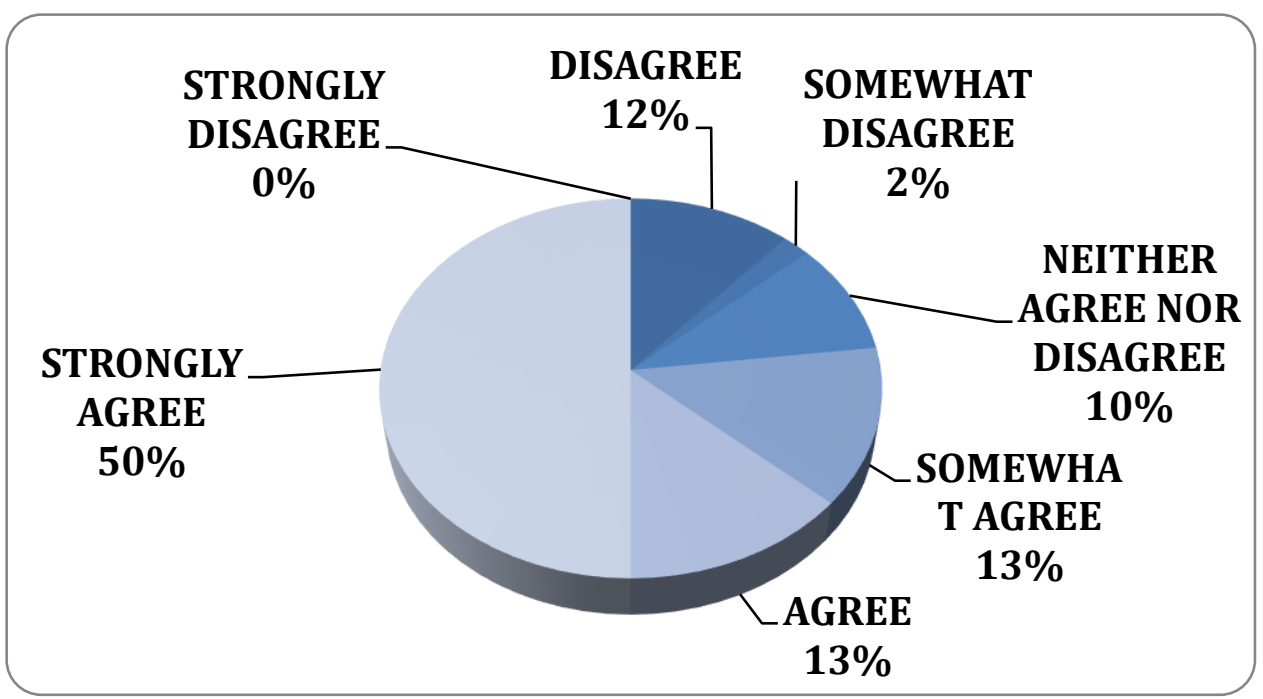

Fig. 3. Would HR directors make the effort to review only the ePortfolio of the best candidate for a job? 
In the fourth item, the respondents were asked whether they would make the effort to review the ePortfolios of the three best candidates for a position.

As indicated in the figure below, $66 \%$ of the surveyed HR directors agreed that they would review the ePortfolios of the three best candidates, with half strongly agreeing and the other half agreeing. In addition, $20 \%$ of respondents somewhat agreed with this statement. In total, they accounted for $86 \%$ of the survey participants. A group of $14 \%$ neither agreed nor disagreed. It is worth mentioning that nobody disagreed, somewhat disagreed or strongly disagreed with the question raised.

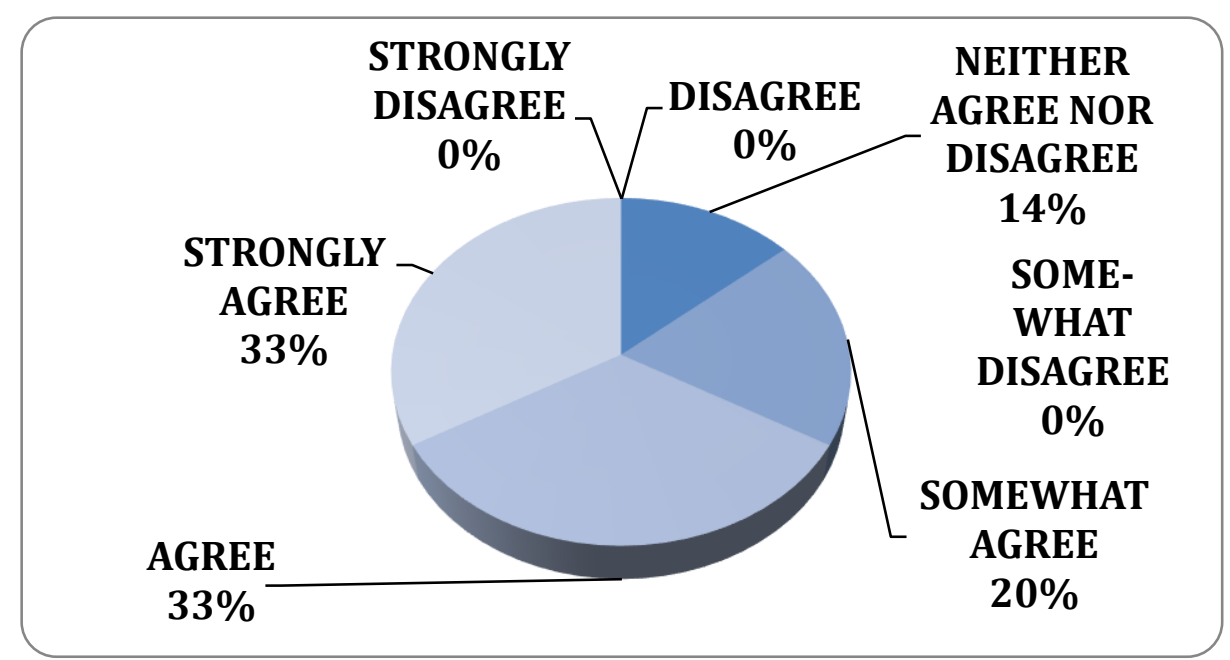

Fig. 4. Would HR directors make the effort to review the ePortfolio of the three best candidates for a job?

The fifth question was aimed at exploring whether the survey participants would be willing to review the ePortfolios of all the candidates in order to select the most successful one for a employment. The data shows that $57 \%$ of the HR directors would definitely review the ePortfolios of all the candidates who applied for a job, among them $14 \%$ agreed, $12 \%$ strongly agreed and $31 \%$ somewhat agreed. On the other hand, $15 \%$ of the survey participants neither agreed nor disagreed, $10 \%$ somewhat disagreed, $10 \%$ disagreed and $8 \%$ strongly disagreed. 


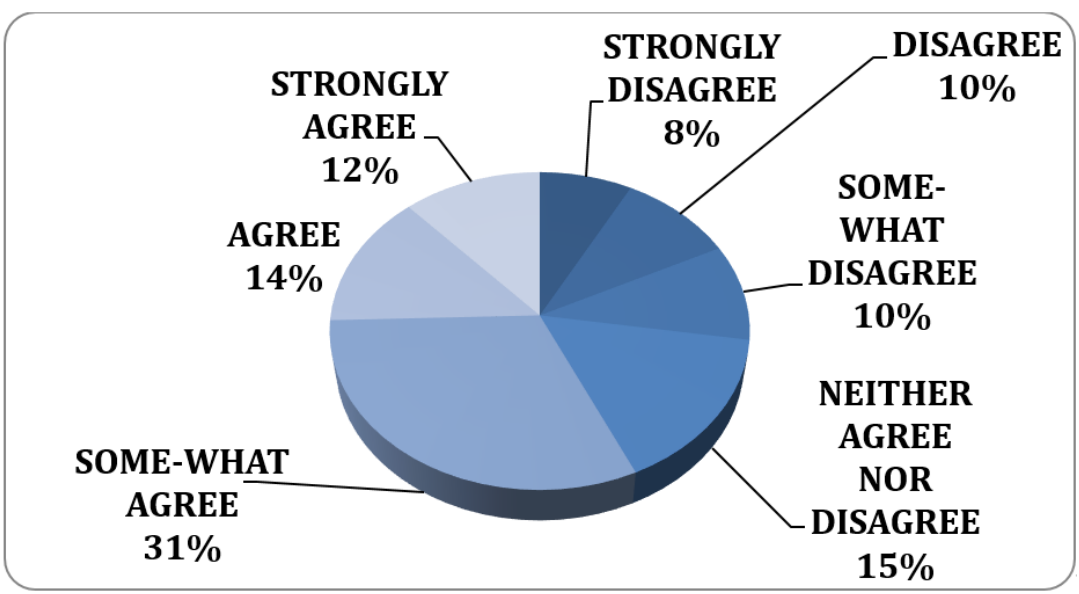

Fig. 5. Would HR directors make an effort to review the ePortfolios of all candidates to select the best ones for a job?

In the last question, the participants were asked whether they believed that the ePortfolio could be a useful tool to obtain information on the candidates for a job post.

The vast majority of the HR directors that participated in the survey, $80 \%$ to be exact, considered the ePortfolio to be a useful tool to obtain broader and more detailed information on the candidates vying for a job, among those $36 \%$ strongly agreed, $30 \%$ agreed and $14 \%$ somewhat agreed. On the other hand, those that neither agreed nor disagreed account for $16 \%$ of the total, while $4 \%$ either disagreed or somewhat disagreed.

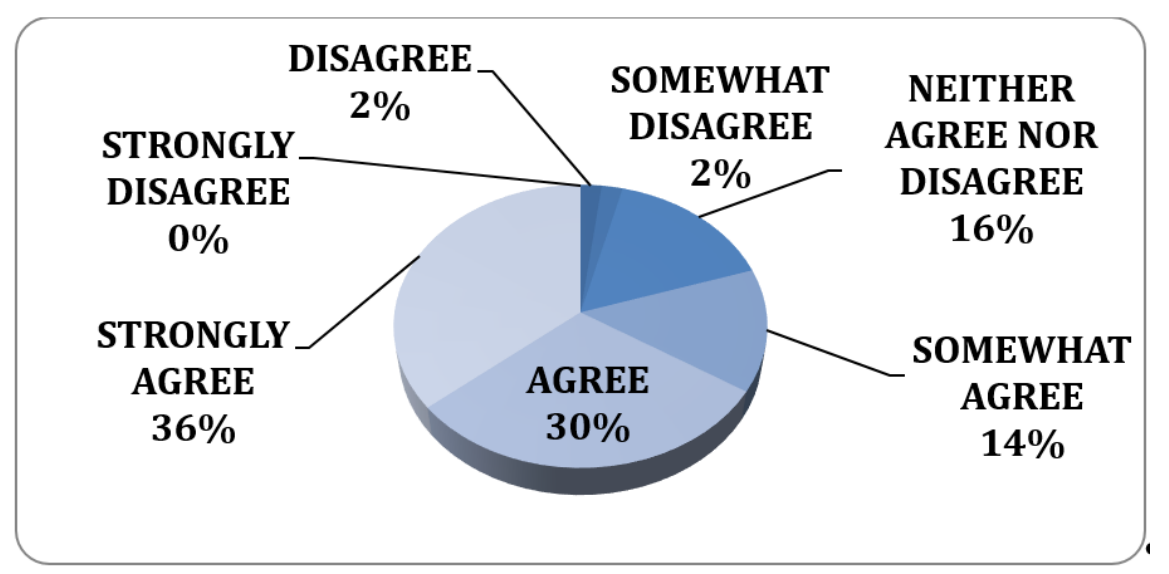

Fig. 6. Do HR directors consider the ePortfolio a useful tool to obtain wider and more detailed information on candidates who apply for a job? 


\section{Conclusion}

The research findings indicate that $83 \%$ of respondents would use an ePortfolio to select candidates for a job at some stage of the recruitment process. Seventy-six percent claim that they would review the ePortfolio of the best candidate and $86 \%$ would review it for the three best candidates. It is worth mentioning that $57 \%$ of the surveyed HR directors claimed that they would review the ePortfolios of all applicants. Finally, $80 \%$ of HR directors who participated in the survey considered the ePortfolio a useful tool to obtain wider and more detailed information on candidates who apply for a job. These findings coincide with the results of the survey conducted for the Association of American Colleges and Universities (AAC\&U) by Hart Research Associates [38], which found that $83 \%$ employers surveyed considered that students' ePortfolios could be useful to demonstrate that the candidates for employment have the knowledge and abilities to succeed. These findings are also in line with those of Ward and Moser [29], Yu [30], Watty et al. [35], Weber [26] and Ambrose [41].

The conclusion that can be drawn from this research suggests that HR directors are interested in the potential of the ePortfolio for decision making related to recruitment. This study is relevant as it provides valuable information on the ePortfolio as a recruitment tool and it is the only one to date, conducted among HR directors in the context of Spanish-speaking countries. The majority of studies on this topic have been conducted in the USA and Australia.

After having analyzed the findings, an essential question needs to be asked: is it worth implementing the ePortfolio in the curricula of college and university degrees? The answer is a resounding YES. Resources that can help students find employment and to reduce the existing gap between the academic and professional worlds are valuable and should be implemented with enthusiasm.

The findings of this study can serve to obtain an indicative approximation on the topic and pave the way for additional inquiries needed in the Spanish-speaking context. One of the limitations of this study is the demographic representation, therefore, it could be expanded in future research. Additionally, future analyses might include a qualitative and quantitative study on the effectiveness and usefulness of ePortfolios as a recruitment tool conducted among job applicants, as well as on the implementation of ePortfolios in colleges and universities in the Spanish-speaking context.

\section{$5 \quad$ References}

[1] Declaration, B. (1999). Towards the European Higher European Area. In Conference of Ministers responsible for Higher Education in (Vol. 29).

[2] Crosier, D., \& Parveva, T. (2013). The Bologna process: Its impact in Europe and beyond. UNESCO. Retrieved from: http://unesdoc.unesco.org/images/0022/002206/220649e.pdf

[3] Delors, J. (1996). Report to UNESCO on Education for the 21st Century-Learning: The Treasure Within. Retrieved from: http://unesdoc.unesco.org/images/0010/001095/109590 $\underline{\text { eo.pdf }}$

[4] Watson, L. (2003). Lifelong learning in Australia. Department of Education, Science \& Training. Retrieved from: http://hdl.voced.edu.au/10707/72789 
[5] DEST. Australia. Department of Education, Science, and Training. (2002). Employability skills for the future. Retrieved from: http://www.voced.edu.au/content/ngv\%3A12484

[6] Ciesielkiewicz, M., \& Coca, D. M. (2013). The Electronic Language Portfolio as a Tool for Lifelong Learning. In Conference proceedings. ICT for language learning (p. 464). libreriauniversitaria. it Edizioni. Retrieved from: http://conference.pixel-online.net/

ICT4LL2013/common/download/Paper_pdf/225-SIM03-FP-Ciesielkiewicz-ICT2013.pdf

[7] Dorninger, C., \& Schrack, C. (2008). Future learning strategy and ePortfolios in education. International Journal of Emerging Technologies in Learning, 4 (1), 11-14.

[8] Centre for Recording Achievement [CRA]. (2019). International Case Studies - Center for Recording Achievement. Retrieved from: http://www.recordingachievement.ac.uk/ international/case-studies-375762.html

[9] European Institute for E-Learning [ElfEL]. (2019a). ePortfolio for all. Retrieved from: http://www.eife-l.org/activities/campaigns/

[10] European Institute for E-Learning [ElfEL]. (2019b). EuroPortfolio. Retrieved from: http://www.eife-l.org/about/europortfolio

[11] Europass. (2018). What's New? Retrieved from: https://europass.cedefop.europa.eu/about/news

[12] Joint Information Systems Committee [JISC]. (2019a). e-Portfolios. Retrieved from: https://www.webarchive.org.uk/wayback/archive/20140614001815/. http://www.jisc.ac.uk/whatwedo/topics/eportfolios.aspx

[13] Electronic Portfolio Action and Communication [EPAC]. (2019). EPAC community of practice: Electronic portfolio action and communication. Retrieved from: http://epac.pbwiki.com

[14] National Coalition for Electronic Portfolio Research [NCEPR]. (2019). Members. Retrieved from: http://ncepr.org/members.html

[15] IMS Global Learning Consortium Inc. [IMS Global]. (2019). IMS Global Around the World. Retrieved from: http://www.imsglobal.org/ims-global. https://doi.org/10.1201/ 9781420064612.sec2

[16] Joint Information Systems Committee [JISC]. (2019b). The e-portfolio implementation toolkit. Retrieved from: https://epip.pbworks.com/w/page/28670505/The\%20e-portfolio\%20implementation\%20toolkit

[17] Brown, G., Chen, H. L., \& Gordon, A. (2012). The Annual AAEEBL Survey at Two: Looking Back and Looking Ahead. International Journal of ePortfolio, 2(2), 129-138. Retrieved from: http://www.theijep.com/pdf/IJEP93.pdf

[18] Dahlstrom, E., Walker, J. D., \& Dziuban, C. (2013). ECAR study of undergraduate students and information technology, 2013. Louisville, CO: EDUCAUSE Center for Analysis and Research. Retrieved rom:https://library.educause.edu/ /media/files/library/2013/9/ers1302pdf.pdf?la=en

[19] Rowley, J. L. (2016). ePortfolios in Australian Universities. Springer Verlag, Singapor. doi: 10.1007/978-981-10-1732-2

[20] Hallam, G. C., Harper, W. E., Hauville, K. L., Creagh, T. A., \& McAllister, L. M. (2011). Australian ePortfolio Project-Stage 2 ePortfolio use by university students in Australia: Developing a sustainable community of practice Case studies extracted from the final project report December 2009. Australian ePortfolio Project-Stage 2. ePortfolio use by university students in Australia: Case studies extracted from the final project report. Retrieved from: http://www.eportfoliopractice.qut.edu.au/docs/AeP2_Final_Report_Case_Studies. pdf. https://doi.org/10.1080/07294360903510582

[21] Barker, A. (2005). E-Portfolio tools and services: State of the art of e-portfolio technologies. In Abstract for Keynote at ePortfolio Forum Austria. Retrieved from:http://www.eife1.org/activities/projects/epicc/final report/WP2/EPICC2 17 Baker ePaustria paper.pdf 
[22] Pegrum, M., \& Oakley, G. (2017). The changing landscape of e-portfolios: Reflections on 5 years of implementing e-portfolios in pre-service teacher education. In E-portfolios in higher education (pp. 21-34). Springer, Singapore. https://doi.org/10.1007/978-981-10-3803-7_2

[23] Zeichner, K., \& Wray, S. (2001). The teaching portfolio in US teacher education programs: What we know and what we need to know. Teaching and teacher education, 17(5), 613-621. doi: https://doi.org/10.1016/s0742-051x(01)00017-8

[24] Vozzo, L., Hatton, C., Reid, J., Pietsch, M., Bennet, M., Nanlohy, P., Labone, E. (2014). Assessing Professional Teaching Standards in Practicum Using Digital Technologies with Aboriginal and Other Pre-service Teachers. Retrieved from: http://www.olt.gov.au/system/files/resources/PP10 1817 Vozzo Report 2014.pdf.

[25] Zhou, M., \& Helms, M. M. (2015). Perceptions of Preservice Teachers' E-Portfolios for Hiring Decisions. Georgia Educational Researcher, 12(1), 119. doi: https://doi.org/10.20 $\underline{429 / g e r .2015 .120106}$

[26] Weber, K. (2018). Employer Perceptions of an Engineering Student's Electronic Portfolio. International Journal of ePortfolio, 8(1), 57-71.

[27] Lievens, R. (2014). A Proposal: Mitigating Effects of the Economic Crisis with Career ePortfolios. International Journal of ePortfolio, 4(2), 157-168. Retrieved from: http://theijep.com/pdf/IJEP139.pdf

[28] Leahy, R. L., \& Filiatrault, A. (2017). Employers' Perceptions of the Benefits of Employment Electronic Portfolios. International Journal of ePortfolio, 7(2), 217-223.

[29] Ward, C., \& Moser, C. (2008). e-Portfolios as a hiring tool: Do employers really care? Educause Quarterly, 31(4), 13-14. Retrieved from: http://er.educause.edu/articles/2008/11/ eportfolios-as-a-hiring-tool-do-employers-really-care

[30] Yu, T. (2011). E-portfolio, a valuable job search tool for college students. Campus-Wide Information Systems, 29(1), 70-76. doi: https://doi.org/10.1108/10650741211192064

[31] Blair, R., \& Godsall, L. (2006). One school's experience in implementing E-portfolios. Quarterly Review of Distance Education, 7(2), 145-153.

[32] Hanum, S. R., Che-Ani, A. I., Johar, S., Ismail, K., \& Razak, M. Z. A. (2016). ePortfo-lio: A descriptive survey for contents and challenges. International Journal of Emerging Technologies in Learning, 11(01), 4-10. https://doi.org/10.3991/ijet.v11i01.4900

[33] Johnsen, H. L. (2012). Making Learning Visible with ePortfolios: Coupling the Right Pedagogy with the Right Technology. International Journal of ePortfolio, 2(2), 139-148. Retrieved from: http://www.theijep.com/pdf/IJEP84.pdf

[34] Pegg, A., Waldock, J., Hendy-Isaac, S., \& Lawton, R. (2012). Pedagogy for employability. Retrieved from: http://oro.open.ac.uk/30792/

[35] Watty, K., McKay, J., Ngo, L., Holt, D., McGuigan, N., Leitch, S., \& Kavanagh, M. (2016). ePortfolios in business education: a national study of ePortfolio implementation 2013 to 2015. Retrieved from: http://hdl.handle.net/10536/DRO/DU:30082850

[36] Wongwanich, S., \& Tangdhanakanond, K. (2012). Teacher attitude and needs assessment concerning the use of student portfolio assessment in Thailand's educational reform process. Tarptautinis psichologijos žurnalas: Biopsichosocialinis požiūris, (10), 71-88.

[37] Fung, D., \& Wong, P. S. (2012). Using career education and career services to enhance employability: A case of the Hong Kong Polytechnic University. Asian Journal of Counselling, 19(1), 75-96. Retrieved from: http://www.epforum.eu/sites/www.epforum.eu/files/ePortfolio\%202005.pdf

[38] Ring, G. L., Waugaman, C., \& Brackett, B. (2017). The Value of Career ePortfolios on Job Applicant Performance: Using Data to Determine Effectiveness. International Journal of ePortfolio, 7(2), 225-236. 
[39] Wetcho, S., \& Na-Songkhla, J. (2019). The Different Roles of Help-Seeking Personali-ties in Social Support Group Activity on E-Portfolio for Career Development. International Journal of Emerging Technologies in Learning, 14(2), 124-138. https://doi.org/10.3 991/ijet.v14i02.8718

[40] Hart Research Associates. (2013). it takes more than major employer priorities for college learning and student success. Liberal Education. 99. Retrieved from: http://www.aacu.org/sites/default/files/files/LEAP/2013_EmployerSurvey.pdf

[41] Ambrose, G. A. (2013, April 30). Focus Group Report: What do ND's top recruiters say about Career ePortfolios? // News // ePortfolio@ND // University of Notre Dame. Retrieved August 19, 2019, from: https://eportfolio.nd.edu/news/focus-group-report-what-do-nd-stop-recruiters-say-about-career-eportfolios/

[42] Australian ePortolio Project (2009). Concept guides/AEP survey instruments. Retrieved from: https://research.qut.edu.au/eportfolio/australian-eportfolio-toolkit/

[43] Wuetherick, B., \& Dickinson, J. (2015). Why ePortfolios? Student Perceptions of ePortfolio Use in Continuing Education Learning Environments. International Journal of ePortfolio, $5(1), 39-53$.

\section{Authors}

Monika Ciesielkiewicz, Ph.D., Associate Professor, School of Education, Department of Applied Didactics; Villanueva-Complutense University of Madrid, Spain. Address: Villanueva-Universidad Complutense Madrid. Costa Brava 2, 28034. Madrid, Spain. Email: mciesielkiewicz@ villanueva.edu

Claire Frances Bonilla, MSc in Education and New Technologies, Contributor Researcher, Department of Computer Science, UDIMA - Universidad a Distancia de Madrid. Madrid, Spain. Email: clairefbonilla@gmail.com

Carlos Olave Lopez de Ayala, Global Head of HR at LG Electronics, LG Twin Towers, 128 Yeoui-daero, Yeongdeungpo-gu, Seoul, 07336 Korea. Email: carlos.olave@lge.com

Article submitted 2019-08-21. Resubmitted 2019-11-25. Final acceptance 2019-11-25. Final version published as submitted by the authors 